\title{
EFFECT OF PERSONALITY, ORGANIZATIONAL CLIMATE, AND WORK SATISFACTION ON ORGANIZATIONAL CITIZENSHIP BEHAVIOR TEACHER IN SECONDARY HIGH SCHOOL IN THE CITY OF ADMINISTRATION JAKARTA CENTER PROVINCE DKI JAKARTA
}

\author{
ASARI \\ Vocational High School Negeri 35 Jakarta \\ asari@gmail.com
}

\begin{abstract}
The purpose of this research is to study the influence of personality, organizational climate, and job satisfaction toward the Organizational Citizenship Behavior of teachers at public vocational high school in Central Jakarta Administration city of DKI Jakarta province. This research uses quantitative approach with survey method. The population of this research is all civil servant teachers at 14 public vocational high schools in Central Jakarta Administration. The number of samples of the study were 212 teachers who were taken with the Slovin formula of a population of 451 teachers. Data collection of research with questionnaires then analyzed descriptive statistics and inferential statistical path analysis. Based on hypothesis testing, 1) there is positive direct effect of personality toward Organizational Citizenship Behavior, 2) there is positive direct effect of organizational culture toward Organizational Citizenship Behavior; 3) there is positive direct effect of job satisfaction toward Organizational Citizenship Behavior; 4) there is positive direct influence Personality to Job Satisfaction, and 5) there is a direct positive influence of organizational climate on Job Satisfaction. Thus to improve OCB teachers in vocational high schools by improving teacher personality, quality organizational climate, increasing teacher job satisfaction.
\end{abstract}

Keywords: Organizational Citizenship Behavior, Personality, Organizational Climate and job saticfication

The position of teachers in the school education system has an important and major role. Teachers become the main actors and determine in the process of education in school. The duties and responsibilities of teachers in the implementation of education realize the vision and mission of national education. Qualified teachers become one of the main prerequisites in improving the quality of national education. A Gallup poll quoted by Jones and Walters points to the facts in the general public who argue that the best way to develop educational values is to improve the quality of teachers (Jones, 2008: 130).

Challenges of human resource management in educational institutions, especially educators (teachers), namely the aspect of equity and competence. Indicators of the quality of human resources of the organization or company viewed from the level of quality and productivity. Organizational human resource performance that contributes quality and productivity. Implementation of human resource management principles in educational institutions is expected to improve school competitiveness. According to Moeheriono there is a shift in the paradigm of educational human resources, human resources management is a strategic area of the organization and should be viewed as an extension and development of traditional management ways to manage people effectively and modernly (Moeheriono, 2009: 194).

The advantages of school organization one of them supported by human resources (sdm) a superior teacher. Teachers who have a competitive advantage for school organizations not only have competencies that are in line with the standards, but also have extreme behavior toward school 
organizations. Organizational Citizenship Behavior (OCB) teacher is one of the competitiveness of school organization. OCB is a form of employee behavior by volunteering to perform tasks outside of its role without relating to rewards. The OCB behavior of teachers in schools contributes positively to progress and improves the productivity of school organizations. Teachers with high OCBs are a capital of excellence and enhance the competitiveness of school organizations.

According to Organ, organizational citizenship behavior (OCB): "Individual behavior that is discretionary, not directly or explicitly recognized by the formal reward system, and in the aggregate promotes the efficient and effective functioning of the organization." (Organ, 2006: 3). OCB as an individual behavior that has the freedom to do, where indirectly or not is explicitly recognized reward system, and gives benefit to the effectiveness and efficiency of organizational functions. The definition of OCB contains two main behaviors: 1) free, voluntary, non-self-interest but for others (co-workers, groups, or organizations), and 2) not formally instructed, not recognized by a formal compensation or reward system.

The organs explain the cause of the OCB behavior of workers in the environment where the work is related to attitude and personality. The concept of attitude in work related to job satisfaction (job satisfaction). Steve Jex (p.105) explains why workers are bound to OCB. First, the main cause of OCB is positive affection (positive affect), especially in the form of job satisfaction. Theoretically this view comes from a rather long history of social psychology research showing that positive mood increases the frequency of help and other forms of spontaneous prosocial behavior. Furthermore, positive moods and helpful behaviors actually strengthen each other because helping others usually make people feel good. The second explanation about the cause of the emergence of OCB workers is the cognitive assessment of the treatment of justice against workers by the organization. This view is based on the theory of equity (Equity Theory) that is the state of the worker's assessment of his work situation by comparing cognitively between the inputs to the organization and the results they receive. The third explanation of the causes of OCB is leading to the worker's character. Based on this view of course the personality traits affect the individual to be bound to OCB.

Workers' attitudes in the workplace are related to the organizational climate. Based on the theory study shows the relationship between organizational climate and worker behavior. The concept of organizational climate in the opinion of Tagiuri and Litwin is: Organizational climate is a relatively enduring quality of the internal environment of an organization that is experienced by its members, (b) influences their behavior, and (c) can be described in terms Of the values of a particular set of characteristic (attributes) of organization, (Wirawan, 2008: 121). Organizational climate shows the internal quality of the organization's internal organization that has been experienced relatively and perceived by members, influencing member behavior, and describes a set of characteristics of the organization. Based on this concept, organizational climate becomes the distinguishing nature of one organization with another. Characteristics of the organization into a kind of brand or label of an organization.

Looking at the problems based on the literature review and preliminary survey results that show the low behavior of OCB teachers in Central Jakarta vocational schools, the researcher is encouraged to conduct in-depth research on the factors that influence teacher's OCB behavior. In this study further studied about the variables that allegedly have an influence on organizational citizenship behavior that is personality, organizational climate and job satisfaction.

\section{METHOD}

This research is descriptive and verifikatifyang implemented through primary data collection field. In accordance with the purpose of descriptive research is to describe the nature of a situation that is temporarily running at the time of research done and examine the causes of a particular symptom. This research is descriptive using survey method. Data analysis model using path analysis approach (path analysis). Analysisdigunakan path models to analyze patterns of relationships between 
variables in order to determine the effect of directly or indirectly, a set of free variables on the dependent variable. (Riduwan and Sunarto, 2011: 140). This research will analyze the influence of one variable to another variable. Exogenous variables are personality (X1) and organizational climate (X2). Variable endogenyaitu job satisfaction (X3) and organizational citizenship behavior (X4) .Populasi this research is all teachers civil servants (PNS) padasekolah secondary vocational (SMK) land administration areas of Jakarta Central Jakarta province. The number of schools that become the research place is 14 State Vocational Schools in Central Jakarta Administration City area of DKI Jakarta province. The number of the target population as a whole is as much as 451 teachers with civil servant status sipil.Penentuan sample size of the entire target population using Taro Yamane formula or Slovin.Jumlah sample sebanyak212 teachers.

\section{RESULT}

Hypothesis testing using path analysis. The calculation result obtained by path coefficient indicating influence between variables are: 1) Personality (X1) to Organizational Citizenship Behavior (X4) p41 = 0,303; 2) Organizational Climate (X2) on Organizational Citizenship Behavior (X4) p42 = 0,137; 3), Job Satisfaction (X3) to Organizational Citizenship Behavior (X4) p43 = 0,523; 4) Personality (X1) on Job Satisfaction (X3) p31 = 0.402; 5) Organizational Climate (X2) on Job Satisfaction (X3) p32 $=0.32$. From the acquisition of the obtained path coefficient, it can be shown in the research model that shows the influence of each variable and coefficient value of each lane diagram as follows:

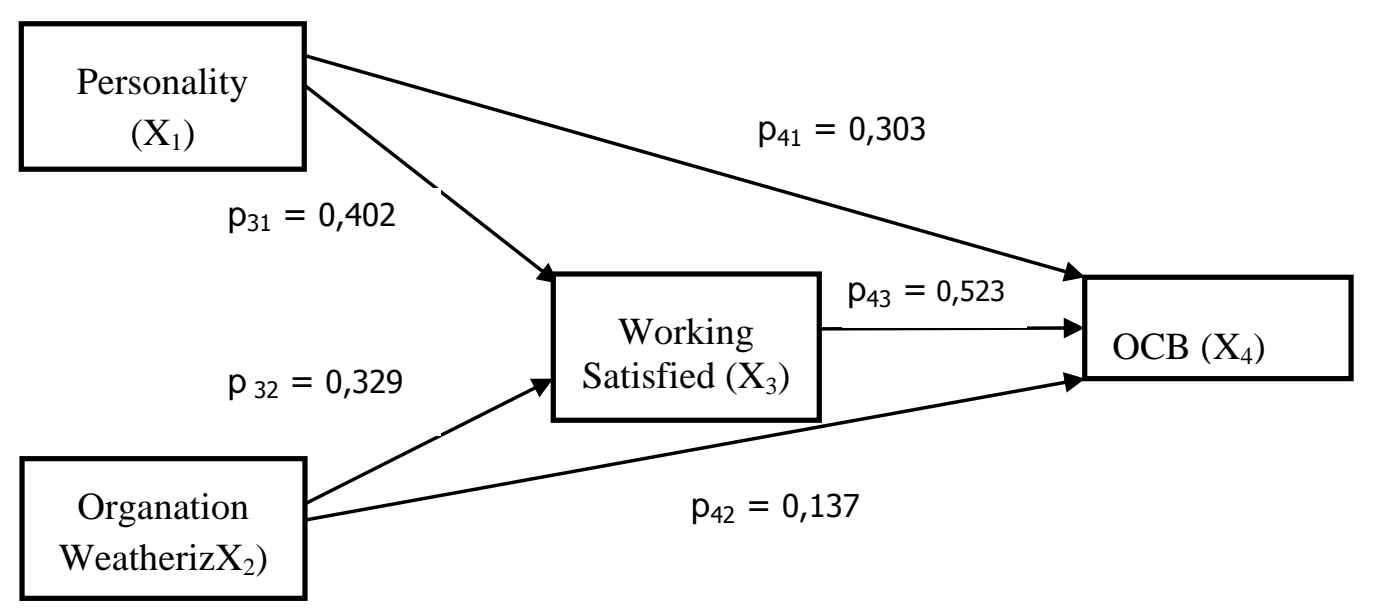

Figure 1. Model Research Structure Based on the Result of Path Analysis

Table 1. Recapitulation of Hypothesis Testing Results

\begin{tabular}{|l|l|l|l|l|l|l|}
\hline No & Hypothesis & $\begin{array}{l}\text { HypothesisS } \\
\text { tatistics }\end{array}$ & $\begin{array}{l}\text { Coefficien } \\
\text { tPath }\end{array}$ & $\begin{array}{l}\text { Tcount } \\
\text { dk 210 }\end{array}$ & Ttable & Decision \\
\hline 1 & $\begin{array}{l}\text { Personality has a } \\
\text { direct positive effect } \\
\text { on OCB }\end{array}$ & $\begin{array}{l}\mathrm{H}_{0}: \beta_{41} \leq 0 \\
\mathrm{H}_{1}: \beta_{41}>0\end{array}$ & $\mathrm{p}_{41}=0,303$ & 6,186 & 1,64 & $\begin{array}{l}\mathrm{H}_{0} \text { Rejected } \\
\mathrm{H}_{1} \text { accepted }\end{array}$ \\
\hline 2 & $\begin{array}{l}\text { The organization's } \\
\text { climate has a direct } \\
\text { positive effect on } \\
\text { OCB }\end{array}$ & $\begin{array}{l}\mathrm{H}_{0}: \beta_{42} \leq 0 \\
\mathrm{H}_{1}: \beta_{42}>0\end{array}$ & $\mathrm{p}_{42}=0,137$ & 2,885 & 1,64 & $\begin{array}{l}\mathrm{H}_{0} \text { Rejected } \\
\mathrm{H}_{1} \text { accepted }\end{array}$ \\
\hline 3 & $\begin{array}{l}\text { Job satisfaction has a } \\
\text { direct positive effect } \\
\text { on OCB }\end{array}$ & $\begin{array}{l}\mathrm{H}_{0}: \beta_{43} \leq 0 \\
\mathrm{H}_{1}: \beta_{43}>0\end{array}$ & $\mathrm{p}_{43}=0,523$ & 10,163 & 1,64 & $\begin{array}{l}\mathrm{H}_{0} \text { Rejected } \\
\mathrm{H}_{1} \text { accepted }\end{array}$ \\
\hline
\end{tabular}




\begin{tabular}{|l|l|l|l|l|l|l|}
\hline 4 & $\begin{array}{l}\text { Personality has a } \\
\text { direct positive effect } \\
\text { on job satisfaction }\end{array}$ & $\begin{array}{l}\mathrm{H}_{0}: \beta_{31} \leq 0 \\
\mathrm{H}_{1}: \beta_{31}>0\end{array}$ & $\mathrm{p}_{31}=0,402$ & 6,757 & 1,64 & $\begin{array}{l}\mathrm{H}_{0} \text { Rejected } \\
\mathrm{H}_{1} \text { accepted }\end{array}$ \\
\hline 5 & $\begin{array}{l}\text { Climate organization } \\
\text { directly positive } \\
\text { effect on job } \\
\text { satisfaction }\end{array}$ & $\mathrm{H}_{0}: \beta_{32} \leq 0$ & $\mathrm{H}_{1}: \beta_{32}>0$ \\
\hline
\end{tabular}

\section{DISCUSSION}

1. Positive Direct Influence Personality toward Organizational Citizenship Behavior (OCB)

Based on the results of statistical calculations with hypothesis test path analysis of the research of the influence of personality (X1) on Organizational Citizenship Behavior (X4) obtained significant path coefficient. The result of the research proves that there is a direct positive influence of personality toward Organizational Citizenship Behavior of Vocational School teacher of Central Jakarta.

One factor causing the emergence of OCB behavior according to Steve Jex (2002: 106) is leading to the character of workers. Based on this view of course the personality traits affect the individual to be bound to OCB. The point of view of human personality is basically most people have the nature of prefer to help others.

The results of this study provide an alternative effort to improve teacher OCB behavior is to consider the personality factor. OCB as an extra behavior that contributes greatly in improving the effectiveness of achieving organizational goals. Teachers with OCB contribute to improving the quality of school education. Teacher personality should be the focus of attention in making changes in the learning process in school. According to Rhenald Kasali the five personality traits "the big five factor" are each the elements of the shaping nature of change or change DNA, (Kasali, 2007: 66). Kasali further uses the term personality dimension with the OCEAN acronym, (Openness to experience, Conscientiousness, Extraversion, Agreeableness, Neoroticism) any kind of openness. That is the openness to life experience, the heart and the ears, the openness of others, the openness to the agreement, and the openness to the pressures. To optimize the impact of personality factors according Kasali use the term Re Codeterhadap ChangeDNA.Re Code in the process of change means we start by doing 'treatment' on some people are limited by looking for anyone among them who can bring that change to more people, (Kasali , 2007: 179).

The results of this study became a concern for the principal as the direct superior of the teacher. One of the principal's tasks is to foster the personality aspect of the teacher. The ability of the principal in personality coaching also determines the change in teacher personality that leads to OCB. The principal is required to compete in order to optimize the personality potential. The principal as a teacher builder in the school has a strategic role in the effort to establish OCB teachers through the optimization of the personality traits that each teacher has.

\section{Positive Direct Influence Organizational Climate Organizational Citizenship Behavior (OCB)}

Based on the study of organizational climate theory shows the internal quality of the organization that has been running relatively long experienced and perceived by the members, affect the behavior of members, and describe the characteristics of charactistics of the organization. The embodiment of organizational climate in the form of perceptions, attitudes and behavior of citizens. Members' perceptions about their organizational environment will affect attitudes and behaviors. The results of the study are in accordance with findings by Jennifer ShuJen Lin and Shu-Cheng Lin (2011) relating to the organizational influences on OCB when workers 
have a sense that they are valued and cared for by the organization, they will better display the service orientation of organizational citizenship behavior.

The results of this study are important for the stakeholders concerned with the organization of the school. The principal has an important role to improve the quality of the school organization's climate. The quality of teachers' perceptions of the organizational climate with the autonomy of teachers in performing their professional duties, trust in the leadership of the workplace organization, the support of the organization's social environment, the appreciation of achievement, and the emotional attachment to the organization. In accordance with Cheng's research (in Garg, 2006) found that the major factors affecting teacher OCB are the quality of teacher relationships with school administration personnel, employment support, equity rewards from schools and other feedback, procedural justice, and job satisfaction.

A positive attitude caused by the perception of organizational climate quality will improve OCB behavior. The results of this study indicate teachers' perceptions about organizational climate in the environment of SMK affect the formation of positive attitude and continue to trigger the growth of OCB behavior in SMK teachers. This means that the organizational or institutional aspects affect the behavior of its members. School is an organizational environment where teachers perform job duties. A conducive school organization climate that will create positive perceptions for teachers in work. The atmosphere of the mind and the positive heart of the teacher in the school environment will increase extra behavior (OCB) in carrying out tasks at school.

\section{Positive Direct Influence Job Satisfaction on Organizational Citizenship Behavior (OCB)}

Based on the theoretical study of experts suggest a strong relationship of job satisfaction variable with OCB. Job satisfaction is a worker's attitude about his job. According to Luthan job satisfaction is an emotional response to the situation of work. Emotional responses result from employees' perceptions of their work. This means that job satisfaction shows a person's positive attitude toward his work. In accordance with the opinion of Steve Jex about the cause of the emergence of OCB is from positive affection.

According to Steve Jex (2002: 106) one of the main causes of OCB is positive affection (positive affect), especially in the form of job satisfaction. Theoretically this view comes from a rather long history of social psychology research showing that positive mood increases the frequency of help and other forms of spontaneous prosocial behavior. Further positive mood and helpful behavior (altruism) actually reinforce each other because helping others usually make people feel good.

The results of the study become the guidance for the principal in an effort to improve the OCB behavior of teachers by building a positive attitude on the job or work experience. A positive attitude through pride in the teachers' profession, the school provides the teacher's work facilities with the needs, the teacher feels given the promotion opportunity, the teacher feels positive for the principal's guidance in working, and the presence. The principal as the top school management should pay more attention to the aspects that meet the achievement of teacher satisfaction in carrying out the task. A positive attitude of the teacher with his work will increase the level of job satisfaction, then generate extra behavior in the form of OCB in the school environment.

4. Positive Direct Influence Personality to Job SatisfactionThe results showed that the personality variable

Have a direct positive effect on teacher's job satisfaction at SMK Negeri in Central Jakarta. In other words teacher personality becomes one of the factors causing teacher job satisfaction. Job satisfaction of teachers will increase with the better teacher personality factor in school. The results of this study in accordance with the study of theories about the factors causing job satisfaction. According to Spector the cause of job satisfaction can be classified into two main 
categories, namely the first work environment itself and factors associated with the important impact of work on job satisfaction. Secondly there are some individual factors that bring people to work, (Spector, 1997: 31) .One of the individual factors is the cause of job satisfaction is the opinion kepribadian.Sedangkan Steve Jex (2002: 119) on the nature of the approach to job satisfaction that many workers Who have a tendency to be satisfied or dissatisfied with their work, regardless of the nature of the work or organization in which they work.

Explanation of factors causing job satisfaction with Affective Event Theory, (Robbins, 2009: 332). That is the theory that describes the influence of emotions and mood on performance and job satisfaction. Job satisfaction as a form of response to one's attitude about his work. Personality factors as individual tendencies that will evoke emotional reactions in the form of attitudes toward work. Attitudes consist of cognitive, affection and behavioral aspects. Cognitive aspects that affect a person in interpreting the character of his work. Aspects of affection affect job satisfaction through the effects of feelings (mood) on the workplace.

Personality is one of the individual factors that every teacher has. Character and individual potential of teachers can be maximized in the implementation of tasks as teachers. School principals and school management who have the task of maintaining and growing the teacher's personality to achieve teacher work satisfaction in school. The results of this study in accordance with the study of the theory of personality relationship with job satisfaction.

The behavioral aspect of a person's personality attitude in achieving satisfaction in the workplace. Based on the description of empirical evidence through research or study theory shows the positive and significant influence of the personality variable on job satisfaction.

\section{Positive Direct Influence Climate Organization on Job Satisfaction}

The results of the fifth hypothesis testing proved the positive influence of organizational climate on job satisfaction of teachers of SMK Negeri Jakarta. This means that the contribution and influence of the real variable organizational climate on job satisfaction of teachers SMKN Central Jakarta. In accordance with theoretical studies by Spector (1997: 30). The second factor causing job satisfaction is the work environment. The environmental factors of work on job satisfaction are described in the work characteristic theory of Hackman and Oldham (Spector, 1997: 31). The basis of the work characteristic theory is that people can be motivated by the intrinsic satisfaction they find when performing work tasks.

Based on descriptive and inferential reviews proves that the quality of organizational climate in Central Jakarta vocational high schools affects teacher satisfaction level. A quality school organization climate will support the achievement of a better level of job satisfaction. School principals and school management are more instrumental in improving the quality of organizational climate aspects that exist in the school environment. Based on the study of organizational climate theory gives a picture of the relative stable condition of the workplace organization environment perceived by its members as a result of perceptions and interactions with members that can influence attitudes or behavior toward their work. Organizational climate formed by members' perceptions of the state of the working environment that includes the physical environment of the workplace, social environment, management system, and organizational culture. Based on the results of empirical testing of this study and the study of the theory proves a quality organization climate to shape a person's positive attitude towards his work. Through a positive attitude toward the work formed by the climate of the organization will increase job satisfaction from workers.

\section{CONCLUSION}

Based on the findings of research results through path analysis there is a direct positive influence of personality, organizational climate, and job satisfaction on organizational citizenship 
behavior (OCB) teachers SMKN Central Jakarta. Research findings that teacher's personality, school environment Climate organization, and teacher work Satisfaction contributes to improvement Organizational Citizenship Behavior (OCB) teacher of SMKN Jakarta Pusat. The second findings of this study prove the direct positive influence of personality and organizational climate on job satisfaction. Increased teacher job satisfaction is done by taking into account the teacher's personality aspect and improving the quality of organizational climate in the school environment where the teacher works.

\section{RECOMMENDATION}

The findings of this study indicate that organizational citizenship behavior (OCB) gurudipengaruhi by personality factors, organizational climate, and teacher work satisfaction. The first recommendation for the Provincial Education Office of DKI Jakarta, in formulating policies on the development and development of SMK teachers' resources should pay attention to the teacher's personality aspect, organizational climate quality in the vocational high school environment, and the level of teacher work satisfaction in the school. The education office should have a system of guidance and development aspects of teacher personality especially in vocational high schools, the need to improve the effectiveness of the implementation of Monitoring \& Evaluation (ME) in schools.

The second recommendation for the headmaster of SMK, as the highest leader and manager in the school has a major role in increasing the teacher's OCB behavior. The principal should pay attention to aspects of personality in providing coaching and teacher career development. Principals as leaders for teachers should strive to foster positive attitudes in the teacher's personality aspect. In relation to such efforts the principal should have and understand the personality information of the teacher in the school. The principal will more easily and effectively carry out personality coaching and can improve teacher OCB behavior.

The third recommendation related to the scientific of human resource management, the findings of this study the need for further research and development to more comprehensively review the variables that affect the teacher OCB SMK in Jakarta.

\section{REFERENCES}

Garg, Pooja dan RenuRastogi. (2006). Climate profile and OCBs of teachers in public and private schools of IndiaInternational Journal of Educational Management Vol. 20 No. 7, 2006 pp. 529-541Emerald Group Publishing Limited

Jex, Steve M. (2002). Organizational Psychology A Scientist-Practitioner Approach. New York: John Wiley \& Son Inc.

Jones, James J. \& Donald L. Walters. (2008). Human Resource Management in education, Manajemen Sumber Daya Manusia dalam Pendidikan. Yogyakarta: Q-Media.

Lin, Jennifer Shu-Jen dan Shu-Cheng Lin. (2011). Moderating effect of organizational climate on the relationship of organizational support and service-oriented organizational citizenship behaviors. African Journal of Business Management Vol. 5 (2), pp. 582-595, 18 January.

Moeheriono. (2009). Competency Based Performance Measurement. Jakarta: Ghalia Indonesia.

Noe, Raymond A., Jon R. Hollenbeck, Baary Gerhat, dan Patrick M. Wright. (2010). Human Resource Management: Achieving Competitive Advantages. Jakarta: Salemba empat.

Organ, Dennis W., Philip M. Podsakoff \& Scott B. MacKenzie. (2006). Organizational Citizenship Behavior: Its Nature antecedents and consequences. Californa: SAGE Publications, Inc.

Riduwan dan Akdon. (2009). Formulas and Data in Statistics Applications. Bandung: Alfabeta.

Robbins, Stephen P., Timothy A. Judge. (2009). Organizational behavior. Issue 12 Book 1. Jakarta: Salemba Empat.

Spector, Paul E. (1997). Job Satisfaction. California: SAGE Publishing.

Wirawan. (2008). Culture and Organizational Climate: Application Theory and Research, Second Print. Jakarta: Salemba Empat. 